\title{
A maturing manifesto: The constitutionalisation of children's rights in South African jurisprudence 2007-2012
}

\author{
Julia Sloth-Nielsen and Helen Kruuse
}

\begin{abstract}
This article represents the next in a series of five-year overviews of children's rights in the courts in South Africa. Using the Convention on the Rights of the Child and the African Charter on the Welfare of Children as a point of departure, the study suggests that it is in the public sphere that children's rights have had their most impact in the period under review. The article highlights eight areas of distinction in this five-year period: these include judicial approval of resource mobilisation for the fulfilment of children's rights, emphasis on the quality of and standards in education; the development of innovative remedies to deal with unreasonable state measures affecting children, and an increasing focus on the right to dignity of the child. The authors conclude that the scope of the cases cited points to the growing insertion of children's rights considerations in increasingly diverse areas of legal interaction. Furthermore, the authors posit that the CRC and ACRWC - together with non-binding sources of international law - have substantively informed and enriched the jurisprudence of South African courts.
\end{abstract}

\section{Introduction}

As of 2012, South Africa has experienced 18 years of democracy. Perhaps the most significant aspect of the transition, other than universal adult suffrage, was the adoption of a justiciable Bill of Rights which included an elaborate children's rights clause, inspired by the United Nations Convention on the Rights of the Child (hereafter CRC).

The potentially transformative impact of this constitutionalisation of children's rights was first addressed in an article published in this journal in 1996. It was proposed, then, that the constitutional best interest standard could become

... a benchmark for the review of all proceedings in which decisions are taken regarding children ...

but that the real questions of rights for children would dissolve into questions of redistributive justice: 
it is not the decision making in individual cases involving children that is going to ameliorate the daily lives of children. Gains for children will be measured by rather more substantive improvements. And it is in this regard that the inclusion of (particularly) children's socioeconomic rights in the constitution is likely to make an impact over time (Sloth-Nielsen, 1996: $342)$.

In 2002, a five-year overview was published to review progress made. The interpretation of children's rights in the courts was singled out (Sloth-Nielsen, 2002). Some ten decisions were assessed, loosely divided into public law matters and private law cases involving the CRC. In short, it was then concluded that adults - in pursuit of their own interests - had been the major beneficiaries of the constitutionalisation of children's rights. The disappointing outcome of Government of the Republic of South Africa and others v. Grootboom and others 2000 (11) BCLR 1169 (CC) in (seemingly) extinguishing the promise of children's constitutional social and economic rightswaslamented.

The second five-year update (Sloth-Nielsen and Mezmur, 2007) painted a rather more promising picture. Having overcome the strictures of the private law/public law dichotomy, the 2007 analysis adopted the four pillars of the CRC(non-discrimination, best interests, the right tolife, survival and development and the right of the child to express views) as the methodological framework for considering just more than 20 cases. They were ultimately illustrative of a conclusion that international children's rights law had taken 'a firm root in domestic jurisprudence', and that the deepening of the children's rights project could be ascribed to a maturing legal sector which was more conscious of, and willing to raise, children's rights in defence of their interests. Alluding to the total impact of this evolution being more than the sum of its parts, the article concluded that international children's rights law had become 'an essentialframe of referencein theSouthAfricanlegalsystem'.

This article describes the next five-year period, as seen through court judgments. The flood of worthy case law in the child law sphere has necessitated a far more selective approach than previous overviews. The authors have also eschewed the 2007 'four pillar' CRC analysis. This seemed somewhat artificial, and omittedimportant features of child rightsjurisprudence, notably the issue of resource mobilisation for the realisation of children's rights (article 4 of the CRC and article 1 of the African Charter on the Rights and Welfare of the CRC and article 1 of the African Charter on the Rights and Welfare of the Child, hereafter ACRWC), ${ }^{1}$ and to a lesser extent, children's right to dignity (see below). Moreover, the best interests of the child principle, one of the four pillarsandconstitutionalisedinsection 28(2) of the South African Constitution, is overarching, and almost every case could be situated under this heading. Further, courts deal with the right to survival and development almost tangentially, and case law suitable to fit under this heading is sparse and contrived.

\footnotetext{
${ }^{1}$ This could be indicative of the failure of the four pillars to deal with the implementation of rights in the light of available resources as being significant as a criterion for measuring progress. See further the African Child Policy Forum, The African Report on Child Wellbeing: Budgeting for Children (Addis Ababa: 2011).
} 
The framework of the analysis that follows is guided by what we find to be the major jurisprudential reflections of the five-year period. These are, first, the consideration of children's interests as separate across a broad spectrum of matters, whether children are before courts as litigants or not, and extending into an array of settings ranging from procurement issues to tort; second, increased focus on resource mobilisation towards the fulfillment of the children's rights; third, a deepening jurisprudence concerning the quality and content of the right to education; fourth, the crafting of more elaborate remedies aimed at securing child wellbeing; fifth, an emerging emphasis on the child's right to dignity; sixth, an analysis of the widespread and sustained recourse to international law, both 'hard'2 and 'soft', 3 leading to claims that South Africa may have crossed an invisible line from being a dualist to a monist state regarding the incorporation of international law in so far as children's rights are concerned (seeDugard,2005: 37 for ageneral discussion of thesetwoapproaches).

Our final section (section eight) is inspired by Justice Albie Sachs' increasingly famous dictum in $S$ v. M (Centre for Child Law as Amicus Curiae) 2008 (3) SA232 (CC):

Every child has his or her own dignity. If a child is to be constitutionally imagined as an individual with a distinctive personality, and not merely as a miniature adult waiting to reach full size, he or she cannot be treated as a mere extension of his or her parents, umbilically destined to sink or swim with them (para 18).

Is it possible, we ask, to conceptualise a 'constitutional child', to be distilled from the gamut of decisionswesurvey?

For reasons of completeness, it is necessary briefly to set out the court structure in South Africa, and to record the coming into effect of two major pieces of legislation domesticating the principles of theCRC and the ACRWCin the periodunderreview.

A five-tier court structure exists in South Africa. First and second, the District and Regional Magistrates' Courts deal with criminal and civil matters on a limited basis. The High Courts formerly known as Supreme Courts - have ten provincial divisions and three local divisions. Their judgments set have ten provincial divisions and three local divisions. Their judgments set precedent in the province over which they have jurisdiction. Fourth, the Supreme Court of Appeal (SCA) is the apex court for all non-constitutional matters (this may change shortly). Fifth, the Constitutional Court is the apex court for constitutional matters. Whilst themain focus of the cases highlighted in this article emanate from the Constitutional Court, some High Court cases are included due to their far-reaching effects and substantiation of the major findings reached.

The Child Justice Act 75 of 2008 and the Children's Act 38 of 2005 took full effect on 1 April 2010. To the extent that CRC and ACRWC principles have now been codified and expanded in local law, the ground for further litigation and judicial elaboration of children'srightshasalso beenlaid.

\footnotetext{
${ }^{2}$ Referring to treaties formally ratified by South Africa.

${ }^{3}$ Referring to Guidelines, General Comments, and other non-binding sources.
} 


\section{Children's Separate Interests}

Our analysis commences where the previous study paused, when the authors anxiously awaited the outcome of argument heard before the Constitutional Court in $S v . M$ (Sloth-Nielsen and Mezmur, 2007: 26-27). This case concerned the impact of the best interests of the child principle in relation to the sentencing of a primary caregiver of minor children. While the High Court had already considered this question as far back as 1998,4 this was the first time the Constitutional Court was faced with theissue. Whilethejudgment is generally regarded as having revolutionised sentencing in similar cases, it has also been used as authority for courts in diverse settings to deal with affected children as a separate consideration.

$S v$. $M$ started as a criminal matter in the Regional Court, where ' $\mathrm{M}$ ' (the mother and sole caregiver of three minor children) had been sentenced to four years' imprisonment for fraud and theft (para. 3). On appeal, M's sentence was replaced with correctional supervision, including an initial short stay in prison. M's appeal to the Constitutional Court was based partially on the contention that the courts below had failed to consider the best interests of the children when imposing a custodial sentence. The Constitutional Court limited the appeal to three questions: (1) What is the role of the sentencing court when sentencing a primary caregiver of minor children?; (2) Having identified these duties, werethey observed in this case?; and (3) if the duties were not observed in this case, what order (if any) should the Court make? (para.5)

In response, the State argued that the current sentencing practice in South Africa adequately dealt with children's best interests. This practice (commonly known as the 'Zinn triad') considered the personal circumstances of the

criminal, including his/her parental obligations, and weighed them against the gravity of the crime and its impact on the community (para. 26). 5 The caustic response of the amicus was that a child of a primary caregiver is not a 'circumstance' and that the interests of the child should not be 'swallowed up by and subsumed' into a consideration of the culpability and circumstances of the primary caregiver (para. 30).

While the Constitutional Court held that the Zinn triad retained its status as the sentencing north star'(para.10,fn.4), theCourtsimultaneouslyfoundthat-

[f]ocused and informed attention needs to be given to the interests of children at appropriate moments in the sentencing process. The objective is to ensure that the sentencing court is in a position adequately to balance all the varied interests involved, including those of the children placed at risk. This should become a standard preoccupation in all sentencing courts (para. 33).

\footnotetext{
${ }^{4}$ In the first author's review in 2002, the High Court cases of $S$ v. Kika (1998 (2) SACR 355 (W) and $S$ v. Howells [1999] 2 All SA 233 (C) were discussed. The best interests of the child were also considered in sentencing a mother of minor children in $S v$. Mamba unreported A618/02 (2002, T) and when considering a bail application in S v. Petersen 2008 (2) SACR 355 (C).

${ }^{5}$ See $S$ v. Zinn 1969 (2) SA 537 (A) at 540G-H.
} 
In accepting the arguments of the amicus, the curator and the applicant, the court set out a comprehensive set of guidelines for the sentencing process, in which courts are enjoined to consider any children of a convicted person as a separateenquiry (para.36).

In applying these guidelines, the Court chose to sentence $\mathrm{M}$ to a non-custodial sentence, which included community service and paying back the victims of her fraud. The Court noted that this type of sentence was more restorative and helped to balance the rights of the offender, her children, the victims and the community (para. $59 \mathrm{ff}$.).

The court also made some valuable comments on the sentencing process in general. First, the court made it clear that it would not be swayed by the narrow thinking (as argued by the state) that offenders with children would be allowed to use their children 'as a pretext for escaping otherwise just consequences of their own misconduct' (para. 35). ${ }^{6}$ This much is clear from the court's finding in the subsequent case of $M S v . S$ (2011 (2) SACR 88 (CC) discussed below) that in appropriate circumstances, it is necessary to sentence a caregiver to a custodial term.

Secondly, the Court situated the constitutional children's rights provision (section 28), as an expansiveresponsetotheinternationalobligations incurred under the $\mathrm{CRC}$, and stated that -

regard must be had to the principles of the CRC as they inform the provisions of section 28 in relation to the sentencing of a primary care-giver. The four great principles of the CRC... guide all policy in South Africa in relation to children, .... What unites these principles e heart of section $28, \ldots$ is the right of a child to be a child and enjoy special care (paras. 16-17).

The Constitutional Court had opportunity to consider the guidelines set out in $S v$. $M$ in the later case of $M S v$.S. Here, the Court made it clear that where the convicted offender was not the sole primary caregiver of the child, the $S v . M$ guidelines were not necessarily applicable. In confirming a mother's custodial sentence, the majority of the Court found that Mrs S. (convicted for fraud and uttering) was not a single parent who was almost exclusively burdened with the care of the children: Mrs S.'s husband was a 'co-resident' parent who was willing to care for the children during her incarceration, even if he had to employ substitute childcare during his long work hours. The court also distinguished Mrs S.'s situation in that there was plenty of information before the trial court about the position of her young children and their care (paras. 63-64). The Court, however, required post-sentencing visits by social welfare authorities to ensure the continued wellbeing of the children of the appellant.

While Khampepe J. was the only judge to dissent, her statements on the role of sentencing courts where children are involved will hopefully filter through to the lower courts. She cautioned that:

[i]f the principles enunciated in $S v . M$ are to serve their purpose, courts must conduct more robust child-centred enquiries to ascertain the impact a custodial sentence would have on the children of primary caregivers, should they be incarcerated. The answer to the question,

${ }^{6} \mathrm{Cf}$ the minority judgment of Madala $\mathrm{J}$ at para. 117. 
whether the sentencing court has observed the guidelines, should ordinarily appear from the record itself, through the reasons that are given on sentence (para. 39).

In addition, Khampepe J. stated that the application of the best interests principle required the court not only to enquire into the alternative care available for the children, but that this enquiry had to focus on the quality of that alternative care (para. 44). The effect of Khampepe J.'s dicta is that it will not suffice for courts to pay lip service to the best interests principle without investigating substantive practical issues around carearrangements (para.36).

It was (ironically) the quality of parental care with which the Constitutional Court concerned itself in a matter dealing with the civil forfeiture of a home in which children lived. In Van der Burg v. National Director of Public Prosecutions [2012] ZACC 12 the applicants asked the Court to set aside the forfeiture order on the basis, inter alia, that the forfeiture was disproportionate in the circumstances, and that it would not be in the best interests of their children if the family were to become homeless (para. 65). It was common cause that the applicants had been illegally running a shebeen 7 from their home for years, and that most of the rooms in the house (including the bedrooms and passage) were used to sell or store alcohol (para. 6). Alcohol use started in the morning were used to sell or store alcohol (para. 6). Alcohol use started in the morning and continued until very late at night, with drunk customers surrounding the house and frequent fights. Evidence was led that more than 50 police actions, including 18 arrests, had taken place on the property (para. 11). As a result of the unlawful activities on the property, and unsuccessful police interventions, the NDPP had successfully sought to have the home forfeited in terms of section 50(1)(a) of the Prevention of Organised Crime Act 121 of 1998.

The High Court found that the property was instrumental in the commission of the crime of selling liquor without a licence and that forfeiture would be proportionate in the circumstances (National Director of Public Prosecutions v. Hilda van der Burg and another (CPD) Case No 5597/06, 22 December 2008, unreported, paras. 29 and 39). The best interests of their four children were first raised by the appellants in their appeal to the Constitutional Court, only after they had unsuccessfully appealed the matter to a full bench of the High Court. ${ }^{8}$

The appellants argued that the Constitutional Court had to approach the forfeiture as if it were an eviction and consider all the relevant circumstances, including the rights and needs of children, as required by South Africa's eviction legislation. In addition, the amicus (the Centre for Child Law) contended that the forfeiture should not be granted until and unless a curator ad litem hadbeen appointed to represent the children'sinterests (paras. 26-27).

The Court held that that the appellants' bald allegation of future homelessness was not borne out by the facts. Notwithstanding, the Court did find that the interests of the children had to be considered separately and could not be dealt with merely as one of several factors weighed on the proportionality scale (as argued by the NDPP): '[T]he impact of social and economic

\footnotetext{
${ }^{7}$ A 'shebeen' in South Africa is an unlicensed liquor outlet.

${ }^{8}$ The court noted that, prior to the admission of the Centre for Child Law as amicus, the issue of the best interests of their children was not pertinently raised by the applicants (para. 65).
} 
circumstances on them will differ in degree to those of adults and deserve separate and focused consideration'. In this regard, the Court found that 'the children's interests require specific and separate consideration, in addition to the attention they might get in the proportionality analysis' (paras. 63 and 70). Importantly, the court found that the prosecuting authority (i.e. the NDPP, an organ of the state) should have considered and raised the issue of the interests of the children in the matter, even when the parents had not raised it. Thus, in addition to the judiciary's obligation to consider the specific interests of the children, the court held that '[o]fficers of the court like the NDPP are expected to assist the court to the best of their ability with all relevant information at their disposal.'This implies, in keeping with $S v . M$ (at para. 36), that any adversarial posture should be relaxed when the interests of children are involved. It is also clear that in any matter, the state may not hold ' $\mathrm{t}]$ he failure of parents to emphasise the interests of their children' against the children (para. 68).

On the facts, the court was not convinced that the appointment of a curator for the children was necessary. The court pegged the need for a curator on whether the court had sufficient information about the children in order to consider their well-being. In this instance, there had been plenty of information about the children available to the High Court, and the concerns relating to the children had been adequately canvassed (paras. 72 and 74 ).

Ironically, though, it was the children's very interests which led the Constitutional Court to query whether the home in question was a suitable environment for their upbringing. The Court questioned whether the activities of the parents (in running a shebeen at home) conflicted with the children's interests in residing in a safe and secure environment (para. 75). While the court did not expressly draw on the CRC, it is clear that the provision in the Children's Act relied on (section 47(1)) is directly informed by the CRC. The Court found that the applicant's children lived in and were exposed to 'circumstances which may seriously harm [their] physical, mental or social well-being' (para .77). 9 As a result, the Court mero motu ordered an investigation as to whether the children of the applicants were in need of care and protection, a step which could potentially have led to the state removing the children from the parents(seesection 155 of theChildren'sAct).

The cases cited above support the conclusion that in a divergent array of matters, children's interests were held to be an independent factor which courts had to consider even when the children were not before the court as litigants. (Further examples are provided in the sections below.) Moreover, no mere lip service would suffice, as proper investigations had to be prepared and put before the courts. Where children's needs appeared to be in peril, post-court investigation or monitoring bysocial services would be ordered. Finally, theobligation to consider children's interests rested, by virtue of the children's constitutional provision, on all involved stakeholders ex lege, including sentencing officers and prosecutors.

${ }^{9}$ As per section 150(1)(f) of the Children's Act. 


\section{Resource Mobilisation}

A second discernible trend lies in the arena of resource mobilisation. A sustained and sophisticated jurisprudence around socio-economic rights has evolved in South Africa, based, inter alia, on the constitutional provisions regarding access to social security (section 27) and the right to housing (section 26). In 2002, reference was made to the groundbreaking decision in Grootboom which ultimately (although positive for socio-economic rights jurisprudence in general) meant that the children's socio-economic rights 'mini-clause' would not be interpreted to allow children direct access to the deliverables referred to in section 28(1)(c) ('the right to basic nutrition, shelter, basic health care and social services'). Subsequent, more positive, socioeconomic rights cases dealing with children's health and social security issues were discussed in the 2007 review (Sloth-Nielsen and Mezmur, 2007: 13-14, 26-27).

It seems inevitable that issues around funding children's rights would end up being the subject of court action given the socio-economic situation of most children in South Africa (for example, see the indicators in the Allpay and education cases discussed elsewhere). Children are major consumers of state services in relation to health care, education, housing and social services. The child recipients of these services are mostly vulnerable, because of socio-economic and family status, and are frequently dependent on the state for survival. Two High Court cases, in particular, have shown the courts' willingness to engage with policy and spending decisions of the state in relation to children.

In National Association of Welfare Organisations and Non-Governmental Organisations and others v. MEC of Social Development, Free State and others (1719/2010) [2010] ZAFSHC 73 (5 August 2010) the essential issue for determination was whether a provincial state department's policy for the funding of non-profit organisations (NPOs) was in accordance with the state's constitutional obligations. These constitutional ${ }^{10}$ and statutory obligations related to the provision of social welfare services to the needy and the vulnerable in the Free State Province, being children in the residential care system, the disabled and the elderly. The department was (and is) largely dependent on NPOs for delivering services mandated by legislation, viz. the Children's Act and the Older Person's Act 13 of 2006. In relation to children, the NPOs involved in the case operated the majority of child and youth care centres in the province ${ }^{11}$ as well as most of the programmes and shelters for street children and other children in difficult circumstances. ${ }^{12}$ All children in the child and youth care centre are children who have been found to be in need of care and protection by a children's court and placed in the centre by order of the children's court.

The essence of the NPOs application was twofold. First, they sought an order declaring that the department was in breach of its constitutional and statutorydutiesinits policyformulation

\footnotetext{
${ }^{10}$ In particular, sections 8, 9, 26, 27, 28, 41(1)(b) and (c), 195(1)(b), (c), (d), (e) and (f) and 237 of the Constitution.

${ }^{11}$ Chapter 13 of the Children's Act. The judgment records that out of the 1,085 beds available in these centres, only approximately 320 beds are provided by the state itself.

${ }^{12}$ Chapter 14 of the Children's Act. The judgment records that at any given time there are approximately 300 street children in the Free State as well as approximately 300 children in difficult circumstances, accommodated in ten shelters. Two types of programmes are utilised to care for these children, namely first, outreach and drop-in programmes and second, shelters. Most of these services are provided by NPOs.
} 
relating toNPOfunding. Second, they sought a structural interdict to compel the department to report back to the courtfor approval of a revised funding policy.

The applicants contended that the formula for determining funding (subsidies) was unreasonable in that the actual amount of the award to an NPO did not represent the full costs of the service (even if one recognised NPOs' own capacities to raise funds). For example, the department acknowledged that at least R2 ooo (USD 250) per month was needed per child in shelters for street children, yet the department paid NPOs a subsidy of between R400 to R500 (USD 50-60) per month. Similarly, the subsidy paid to NPOs per child per month in child and youth care centres fell woefully short of their allocation per child in their own (i.e. state-run) centres of R5 000-R6 750 per month (USD 600-800) and of estimates by the national department of social development (R6 ooo per month (USD 700)), being just over R2000 (USD 250) per month. Furthermore, it was contended that the determination of the final award was unreasonable in that it was essentially the sole prerogative of the department. As a result, the NPOs had to sign the agreement or receive no funding at all.

The court considered the impact of the policy on social welfare services. Its point of departure was Grootboom whereYacoob heldthat:

It follows from ss 28(1)(b) that the Constitution contemplates that a child has the right to parental or family care in the first place, and the right to alternative appropriate care only where that is lacking. Through legislation and the common law, the obligation to provide shelter in ss 28(1)(c) is imposed primarily on the parents or family and only alternatively on the State. The State thus incurs the obligation to provide shelter to those children, for example, who are removed from theirfamilies.....(para 77.Emphasis added).

Hence, the state had the obligation to provide care and protection to children removed from the family environment, such as children removed to child and youth care centres and to shelters for street children. The court relied on section 4(2) of the Children's Act which obliges the state to take 'reasonable measures to the maximum extent of its available resources' to achieve the realisation of the rights of children set out in section 28(1)(b), (c) and (d) of the Constitution.

In the light of these obligations, the court found that the department's 'take it or leave it subsidy' policy was fundamentally flawed and unreasonable. The court did not discount the possibility of the state taking into account that NPOs had or may have resources of their own - only that the fulfilment of a constitutional duty could not be determined arbitrarily, since it was in this case. In this regard, the court employed the reasonableness test developed by theConstitutional Court over the past few years with regard to socio-economic rights (see in general: Liebenberg, 2010). In so doing, it found that the policy rights (see in general: Liebenberg, 2010). In so doing, it found that the policy did not contain a fair, equitable and transparent method of determination of what NPOs should be able to receive as a contribution for the care for children, older persons and disabled persons in need. 
The department returned to the court with its revised draft version of the policy nearly a year later, reported as National Association of Welfare Organization and Non-Governmental Organizations and others v. MEC for Social Development, Free State and others (1719/2010) [2011] ZAFSHC 84 (9 June 2011). The court once again found that the policy was inconsistent with the Constitution. While the policy made potentially adequate provision for a calculation of the funding required by each eligible NPO, one key paragraph of the policy was unreasonable: it rendered this calculation almost pointless by allowing the department to reduce and adjust awards 'by an appropriate percentage' where the aggregate of approved financial awards exceeded the funds allocated to the department.

The Court found that any adjustment contemplated must be consistent with the Bill of Rights as a whole and must be fair, equitable and transparent. In particular, the Court could not ascertain from the policy how the (downward) adjustment would be done, and therefore found it illogical and irrational. The department was therefore ordered back to the drawing board.

The second case is Western Cape Forum for Intellectual Disability $v$. Government of the Republic of South Africa and another (2011 (5) SA 87 (WCC)) [2010] ZAWCHC 544; 8678/2007 (11 November 2010). The case was brought by an umbrella grouping of NPOs in a different province. The backdrop was the failure of the state ${ }^{13}$ to make direct provision for schools or any type of education for children with severe or profound intellectual disabilities. The NPOs challenged the constitutionality of such exclusion, and the minimal financial support provided to NPOs for these children via the provision of a meagre state subsidy from the Department of Health (not Education). The applicants' main contention was that of discrimination in resource allocation: it was common cause that the subsidy for these children was considerably less than that provided for the education of children who were not as severely disabled. Furthermore, no provision was madefor their educational requirements.

The state, as respondent, submitted during argument that for the affected children (viz. those who do not qualify for admission to special schools on the applicable policy), no amount of education would be beneficial; that they were effectively 'uneducable' (paras. 3 and 19). This was heavily disputed by the applicants who led expert evidence to the contrary. The respondents also resources in the socio-economic rights domain generally had to be taken into account. The applicants sought to establish a violation of the positive dimension of the education right failure to provide the children with basic education - as well as the negative dimension, viz. the non-admission of the children concerned to special schools or other schools.

The High Court addressed various dimensions in respect of which a constitutional violation could be inferred, commencing with an infringement of the right to education. ${ }^{14}$ Utilising article 23 of the CRC as a backdrop, the Court averred that article 23's text underscored the universal recognition of the need to provide fully for mentally or physically disabled children (para. 20).

\footnotetext{
${ }^{13}$ As is the case with social grants, the provision of education is both a national and a provincial competency.

${ }^{14}$ The right to of everyone to basic education is contained in section 29 of the Constitution (as opposed to the children's rights clause section 28).
} 
Further supporting this, according to the Court, were articles 11 and 13 of the ACRWC, which provides first for the right of every child to an education 'which shall be directed to the promotion and development of the child's personality, talents and mental and physical abilities to their fullest potential'; and second, for the 'right of every child who is mentally or physically disabled to special measures of protection in keeping with his physical and moral needs and under conditions which ensure his dignity, promote his self-reliance, and active participation in the community' (article 13(1), ACRWC). ${ }^{15}$

The Court opined that the state's reliance on the limits of funding available for education could not justify its action in excluding the affected children: there was no rational connection to a legitimate government purpose. ${ }^{16}$ The state's action raised two issues: first, why the affected children were singled out for manifestly less favourable treatment than others, and second, why any shortage of funds was not imposed on all children equally. The Court stated that: ' $[t]$ he applicants do not ask that the needs of the affected children be met by the provision of extra funds. They ask that the respondent spread the available funds fairly between all children' (para. 26).

A related ground of attack was based on an infringement of the affected children's right to equality (section 9 of the Constitution). The state argued that transforming a historically underfunded and exclusionary education system for children with disabilities required sticking to their 20-year transformation plan (Department of Education, White Paper 6). This plan would see the affected children get funding in the year 2021, with the state justifying such policy on a type of 'statistical incrementalism' (Ngwena and Pretorius, 2012: 98). The court questioned (inter alia) whether the funding decisions of the state were reasonable and justifiable, given the apparent policy choice that the most vulnerable should 'pay the price' instead of the fiscal burdens being sharedbyall(para.29).

As regards a remedy, the applicants, who had negotiated with the state for more than a decade, accepted that the deficiency could not be cured overnight. It also recognised that the court could not prescribe in detail what programme should be established to meet their needs and rights. The request was (similar to National Association of Welfare Organisations and NGOs discussed above) for a structural interdict requiring the respondents to submit a programme to the Court outlining how the breach would be remedied, and for progress reports to be submitted periodically thereafter.

The above cases are High Court matters and a new Grootboom or TAC emanating from the Constitutional Court thus remains to see the light of day. Nevertheless, seentogetherwith the cases discussed in the following category, a new dawn regarding resource mobilisation for the fulfilment of children's rights has emerged in the period under review.

\footnotetext{
15 Article 13(2) is also cited in full. Reference is also made to the provisions of the Convention on the Rights of Persons with Disabilities, ratified by South Africa on 30 November 2007.

16 The test required by s. 36 of the Constitution in respect of any limitation of a right.
} 


\section{The Right to Education}

In the five years under review, the child's right to education has been increasingly emphasised in South Africa, especially in the light of the dire situation of the schooling system. The Committee on the Rights of the Child expressed its concern as far back as 2000 about 'the extent of overcrowding in some areas; ... poorly maintained infrastructure and equipment; [and] shortages of textbooks and other materials' in South African schools. ${ }^{17}$

The recent jurisprudence on the right to education has grappled with two questions. First, it has been concerned with the content of the right to education, referring to article 28 of theCRCin the process. This has put the spotlight on the constituent elements of a quality education. Secondly, it has considered how the best interests principle can act as a right relevant to issues surrounding the education sphere, notably in procurement processes and evictions.

The case of Governing Body of the Juma Musjid Primary School \& others v. Essay NOandothers 2011(8) BCLR 761 (CC) set the tone in three ways. It is the first time that the Constitutional Court directly considered the content of the education right ${ }^{18}$ alongside the best interests principle. Secondly, the court outlined - as is consistent with the duties set out in article 3 of the CRC - the positive obligations of the state in ensuring that the best interests of children are met. Finally, the court outlined how children's rights are to be balanced against other fundamental constitutional rights, specificallytheright toproperty.

The matter reached the Court as an appeal against an eviction order granted by the High Court to a private landowner, the Juma Musjid Trust, against a public school occupying its premises, bringing the right to education and the (constitutionally protected) right to private property into direct conflict. While the Constitutional Court ultimately allowed the eviction to proceed, it found that the High Court had failed properly to consider the best interests of the affected learners when ordering the eviction. The High Court ought to have required the state to provide information on its plans to ensure the affected learners had access to schools for the 2011 school year (para. 3). As a result, the Constitutional Court required the state's plans (paras. $5 \mathrm{ff}$ ). In the appeal, the Court saved most of its ire for the state: it rebuked the state in strident terms for failing to protect the rights of the school's learners by failing to enter into a statutorilyrequired agreement with the Trust to allow the school to operate on its premises. It also criticised the state for failing to pay the school's rent or maintenance costs for over a decade. The Court criticised the state with direct reference to its positive obligation to ensure that children's best interests are considered (para. 66ff.). The Court held that the state was in breach of its constitutional duty to provide the learners with a basic education and its statutory duty to ensure that there are sufficient places in the province's schools for all children of school-going age.

Nkabinde J. provided the most extensive analysis of the positive obligations arising from the right to education.. After explicitly referring to article 28 of the CRC, as well as reviewing a range

17 CRC Committee 'Concluding Observations: South Africa' UN Doc CRC/C/15/Add 122 (2000) para. 34, available at <http://www.unhcr.org/refworld/publisher,CRC,,ZAF,3ae6afc8c,0.html> accessed on 19 May 2012.

18 Prior to Juma Musjid, the Court's only real engagement with the right to a basic education was an obiter comment in Ex Parte Gauteng Provincial Legislature: In re Dispute Concerning the Constitutionality of Certain Provisions of the Gauteng Education Bill of 19951996 (3) SA 165 (CC) para. 9, where it confirmed that the right to a basic education includes positive and negative rights. 
of other international ${ }^{19}$ and regional ${ }^{20}$ human rights instruments, she concluded that 'a basic education' has several important purposes:

The significance of education, in particular basic education, for individual and societal development in our democratic dispensation in the light of the legacy of apartheid, cannot be overlooked. The inadequacy of schooling facilities ... was entrenched by the formal institution of apartheid .... Today, the lasting effects of the educational segregation of apartheid are discernible in the systemic problems of inadequate facilities and the discrepancy in the level of basic education for the majority of learners (para 42. Emphasis added).

Instead of interpreting the right as a mere entitlement to a place in a school for a defined period, Nkabinde J.'s approach reflects on the transformative potential of education, 'seeing it as an important means to address the legacy of apartheid' and suggests that the right to education includes the quality of education received in terms of infrastructure and learner support. ${ }^{21}$ The Juma Musjid case has thus provided a platform for litigation by public interest lawyers regarding the quality of education received in South Africa in some of the poorest provinces in South Africa (McConnachie and McConnachie, 2012). ${ }^{22}$ While most of these cases have been settled, ${ }^{23}$ the CRC Committee's focus on 'the quality of the learning environment' has been an essential strand. A recent example, Centre for Child Law v. Minister of Basic Education (1749/2012) [2012] ZAECGHC60 (3 July 2012) bears reference. This case was occasioned by the state failing to make appointments to vacant posts, and failing to declare the 2012 and 2013-year post establishment (which would include non-teaching staff). Ultimately, the court was called on to resolve one remaining issue in dispute, the remainder having been settled. This was the question of whether the respondents were under a statutory obligation to declare the post establishment for non-teaching staff at public schools, and to fill these posts.

The court concluded that the failure to provide effective support for administrative processes in schools 'has the same effect as the failure to effect post provisioning for teaching staff: without proper administration in schools, the right to basic education is threatened'. In illustration, one school comprising over 100 learners whose governing body was an applicant in the case had had no secretary or receptionist for ten years, had only one cleaner and one security guard with no administrative posts. Another applicant, a special needs school for children with moderate to severe disabilities, had a post allocation of 77 fornon-teachingstaff, of which only 22 werefilled.

\footnotetext{
${ }^{19}$ Namely, article 26 of the Universal Declaration of Human Rights and articles 13 and 14 of the International Covenant on Economic, Social and Cultural Rights.

${ }^{20}$ Article 17 of the African Charter of Human and Peoples' Rights and article 11 of the ACRWC.

${ }^{21}$ CRC Committee 'General Comment 1 on the Aims of Education' UN Doc CRC/GC/2001/1 (2001) para. 22.

${ }^{22}$ McConnachie and McConnachie 'Concretising the Right to a Basic Education' (2012) 139 South African Law Journal 554-590 document the conditions in state schools nationally: 3,544 have no electricity; 2,402 have no access to water while a further 2,611 have an unreliable water supply; close to 1,000 schools have no toilet facilities while over 11,000 rely on pit latrines. Only seven per cent of schools have stocked and functioning libraries; five per cent have functioning laboratories and only ten per cent have working computer facilities.

${ }^{23}$ For example, Centre for Child Law \& others v. Government of the Eastern Cape Province \& others (Centre for Child Law) unreported case no 504/10 ECHC (2010) and School Governing Body of Amasango Career School v. MEC for Education, Eastern Cape (Amasango) unreported case no 504/10 ECHC (2010). For reported cases, see in particular Section 27 and others v. Minister of Education and another (24565/2012) [2012] ZAGPPHC 114 (17 May 2012) where the North Gauteng High Court found that, consistent with international law, the right to a basic education included the provision of text books.
} 
Correctly, the court understood the knock-on effect such staff shortages would have on the right to basic education; even more, it might imperil other fundamental rights, e.g. the rights to dignity or to security of the person, as well as children's rights elaborated in section 28. Moreover, administration would either break down or have to be performed by teachers who have to deviate from the core functions to perform tasks that they are not trained or expected to perform. It was found that there is indeed a statutory obligation to declare post establishments for teaching and non-teaching staff, and to fill these posts for which budget provision would have been made. Clearly the court demonstrated a nuanced understanding of the educational environment beyond the need for teachers and classrooms.

In Western Cape Forum for Children with Intellectual Disabilities, previously discussed, the court displayed a similar recognition of the wider ramifications of the education endeavour, since the order included measures not only to ensure that all children in the province who are severely disabled are provided access to basic education of an adequate quality, but also covered the provision of funds to involved NPOs for facilities, staff, transport and staff training. Expansive recognition of the constituent components of the rights to education is evident from this remedy, for example, theimpact of transport costs on access to education.

Disappointingly, the decision in Freedom Stationery (Pty) Ltd v. MEC for Education, Eastern Cape 2011 JOL 26927 (E) promised more than it delivered in terms of considering the impact of irregular tender processes on children's education rights. However, the judgment is an indication that the provision of stationery is an important component of the right to education. Moreover, whenever children are the recipients of state services, the courts will consider the best interests of the children affected and may - in exceptional circumstances fashion extraordinary remedies impacting on the procurement and commercial interests of third parties.

Freedom Stationery (Pty) Ltd concerned a state tender for the manufacturing and supply of stationery for various schools in the province, most of them being 'no-fee' schools which provide education to poor children. The value of the tender was over R42 million (USD 6 million). The two applicants were notified thattheirapplicationshadmetthedepartment'sapproval(para.11). Without warning, and at the start of the new school year, the department cancelled the tender and awarded the contract to two other companies (para. 14). As a result, the applicants took the decision on review, and applied for an interim interdict prohibiting the department from concluding any agreements to perform the function in dispute (para. 1). The Court granted the interim interdict and unequivocally found the tender process to be irrational and unreasonable (para. 28). It was this interim interdict that was the subject of the judgment. The Centre for Child Law, admitted as amicus, argued that the interdict would deprive approximately 688,482 children of stationery pending the finalisation of litigation and, since this was not in their best interests, the contract should proceed. The amicus effectively asked the court to grant the extraordinary remedy of allowing the contract to proceed despite the procedural irregularities, or in the alternative, for the court itself to appoint a bidder to ensure that the children's right to education would not be compromised. While the court declined to follow either option (by confirming the interdict), the court berated the state for its general 
inaction in dealing with the problem, and asked that non-governmental organisations be enlisted to assist in obtaining stationery forchildren whilethelitigation was finalised (para. 34).

Despite this outcome, the judgment sends out a clear message that service providers with commercial interests in the education (and other) sectors can expect that the best interests of children (as beneficiaries of the services or goods to which the tenders refer) will be taken into account and may impact on the remedy contemplated by the court. The extraordinary remedy of the court in the recent case of Allpay Consolidated Investment Holdings (Pty) Ltd and others v. Chief Executive Officer of the South African Social Security Agency and others (7447/2012) [2012] ZAGPPHC 185 (28 August 2012) - while not in the education sector - certainly confirms this view. Here, despite finding that major procedural irregularities existed in the tender award to a company to provide state social grants, the court ordered the irregular contract to continue on the basis that over 10 million children, as the main beneficiaries of social grants, would be adversely affected (para. 73 ).

The line of cases concerning the implementation of the right to basic education is a recent development, and at the time of writing it appears that more actions have been launched or are being contemplated, including an action to require the department to gazette minimum norms and standards for schools. This litigation has been furthered by the emergence of a broad spectrum of committed public interest litigators, including (beyond the Centre for Child Law) the Legal Resources Centre, Equal Education, an NPO called 'Section 27', and Lawyers for Human Rights. It is likely, then, that thefive-year reviewwhich followsthis onewill be abletoflesh out the constituent elements of the right to basic education in the Constitution and international law, including the CRC.

\section{Remedies}

The period under review provides fresh evidence of courts' willingness to use their powers to fashion creative remedies to further child protection. In the 2002-2007 review, the first author commented on the value of the structural interdict ordered in Centre for Child Law and others v. MECfor Education and others 2008 (1) SA 223 (TPD) in which the Court required the state to provide a report to it on improvements to care and protection facilities for children. In the last five years, the courts haveincreasingly used the report-backmechanisms of the structural interdict to ensure that children's rights are realised. Structural interdicts were ordered, for example, in both the Western Cape Disabilities and DPP, Transvaal v. Minister of Justice and Constitutional Development cases (discussed elsewhere in this article). The court found it appropriate to supervise the implementation of its orders by the state, given that it found that there was 'a disturbing inconsistency between the promises that the laws made and the implementation of the laws' (DPP, Transvaal v. Minister of Justice, para. 201). A court has also gone so far as to prevent the state from closing down a child and youth care facility until such time as the state reported to it (and the court found) that satisfactory alternative arrangements had been made for the children resident in that facility (see para 5 of the order in Jonkerv. The Manager, Gali Thembani/JJSerfontein Schoolandothers (94/2011) [2012] ZAECGHC 12 (19 March 2012)). 
The court fashioned this remedy despite the state's argument that, by ordering that the centre be kept open (and to satisfy the court as to the adequacy of alternate arrangements), the court would be intruding into the area of policy implementation best left to the expertise and experience of the departments in question (page 19). The structural interdict granted also had considerable planning and budgetary implications: the state had to rearrange its finances to keep the centre open while it found alternative arrangements for the children. Justifying its interventionist stance, the court quoted from the now well-known dictum in Minister of Health and Others v. Treatment Action Campaign (No 2) 2002 (5) SA721(CC):

Courts are ill-suited to adjudicate upon issues where Court orders could have multiple social and economic consequences for the community. The Constitution contemplates rather a restrained and focused role for the Courts, namely, to require the State to take measures to meet its constitutional obligations and to subject the reasonableness of these measures to evaluation. Such determinations of reasonableness may in fact have budgetary implications, but are not in themselves directed at rearranging budgets. In this way the judicial, legislative and executive functions achieve appropriate constitutional balance (para. 38).

The order points to the judiciary's willingness to come to the aid of children where it believes that the state has 'failed them'. Here, the Court found a structural interdict to be necessary and berated the state on three related grounds. First, the state failed to provide cogent evidence that closing the centre actually met the best interests of the affected children. Second, it attempted to rely on legal technicalities to avoid dealing with a matter which potentially threatened the best interests of children (in this regard, the state unsuccessfully raised the issue that the applicant - being the grandmother of one of the affected children did not have locus standi). Finally, the Court chastised the state for recklessly putting false averments before the Court (the state alleged that the applicant's grandson was not in attendance at the school - an averment which was patently incorrect). Pickering J. recommended that the state address the interests of children in 'a non-adversarial field of litigation', and that the state's false averments were 'not only ill founded but worthy of censure' (p.28). As a result, the Court ordered the state to pay the costs of the applicant (para 8 of the order, p.30). Reading between the lines, one senses that the way in which the state conducted the case removed any basisfor deferenceto the executive.

The four cases described in this section illustrate that the courts have readily come to the assistance of children where the state has taken patently unreasonable measures in the care and protection of children - with attendant budgetary implications. What is also clear from the cases is that the structural interdicts - by their very nature - affected the content and reach of decisions of theadministration.

In addition to structural interdicts, courts have also seen fit to order welfare enquiries where none were asked for by the parties. Van der Burg illustrates this point, insofar as a welfare inquiry was added to the order of court to ensure that the children's safety and wellbeing were secured. Similarly, in $M S v$. S, the court added a requirement of monthly visits by a social 
worker to its order where the mother of the children was incarcerated and the father was left to careforthechildren (paras.66-67).

Significantly Centre for Child Law v. Minister of Justice and Constitutional Development 2009 (2) SACR 77 (CC) provides a further example of a more intrusive court approach than has previously prevailed. Instead of merely striking down the offending legislation which purported to re-introduce mandatory minimum sentences for children of 16 and 17 years, the Constitutional Court crafted a more expansive remedy: it required the Minister of Justice to compile a report within a specified time listing all affected children who might have been sentenced under the provisions that it had struck down. By this measure the court sought to ensure that appeals could be initiated by, or on behalf of, those children improperly sentenced. By continuing to exercise supervisory jurisdiction over the execution of its order, the court implicitly recognised the importance of ensuring that children did not 'fall through the cracks' of state non-compliance. The only time the court has exercised a similar supervisory jurisdiction over sentencing concerned the state's failure to timeously substitute death sentences with alternative sentences following the court's early landmark ruling that the death sentencewasunconstitutional. 24

The willingness of the courts to assume this type of supervisory jurisdiction indicates that the courts consider effective implementation of the order as important as the finding itself where children's rights are imperiled. The forward-looking nature of the order in Centre for Child Lawv. Minister of Justice may be replicated whenever the courts consider the consequences of noncompliance for children to be irremediable or so serious as to justify ongoing supervision.

\section{Dignity}

Recently, courts have begun to value dignity as a guiding principle in the interpretation of children's rights. Dignity, along with equality and freedom, has been held to be a founding value of the South African Constitution. While a few decisions discussed in this article (for eg. $M v . S$ ) have referred to the 'provision, protection, and participation'hallmarks of analysis of the CRC, we have noted a marked tendency to draw on the established jurisprudence of the Constitutional Court in isolating dignity (especially) as the cornerstone of the value-driven philosophical foundations of constitutionalism. The recent jurisprudence of the South African courts, interestingly, callsintoquestion the absence of therighttodignityasa 'pillar' of the CRC.

While the role of dignity has an obvious part to play in the provision of social benefits to children, courts have increasingly begun to use dignity as a guiding principle in other types of cases.

Reference has already been made to Western Cape Forum for Intellectual Disability. The court found that a violation of dignity was an inevitable consequence for children left out of the state's education subsidy formula:

${ }^{24}$ Sibiya v. Director of Public Prosecutions: Johannesburg 2005 (5) SA 315 (CC) and S v. Makwanyane 1995 (3) SA 391 (CC) respectively. 
From the violations of the right to education and to equality flow the violation of the affected children's right to dignity, as this group of profoundly intellectually disabled children had been marginalized and ignored and in effect stigmatized.... . The inability of the children to develop to their potential, however limited that may be, is a form of degradation (para.46).

Similarly, in Centre for Child Law v. Minister of Basic Education discussed above, the court noted that when school hostels are understaffed, or security and administration in schools is lacking, children's rights to dignity maybe implicated (para. 21).

In $C$ and others $v$. Department of Health and Social Development, Gauteng 2012 [ZACC] 1, the judgment considered how state action could affect both parents' and children's dignity. This matter concerned children in the care system; the complaint relating to the lack of judicial oversight of children removed from their parents (sections 154 and 155 of the Children's Act 38 of 2005(fullyinforcefrom1April 2010)).

$\mathrm{C}$ was the father of a three-year-old girl, and $\mathrm{M}$ the mother of two children aged one and four. $\mathrm{C}$ was a street vendor who repaired shoes at a busy traffic intersection. On the day in question, his older child was with him since his partner was giving birth to their second child in hospital. Ms M, who was visually disabled, begged for a living in the same vicinity, with her older child being her 'guide'. State social workers planned a well-publicised 'raid' to remove children from people found to be begging with children, including Ms M's infant who was still being breastfed. ${ }^{25}$ No court order to found the 'emergency' removal was sought, and in the execution of the removal, the children were taken into care without their parents being informed as to where they were to be placed. Ms M was separated from her breastfed infant, and was dispatched to a facility for persons with visual disabilities located $400 \mathrm{~km}$ away.

While the Children's Act provided for notification of the emergency removal to the parent, guardian or caregiver within 24 hours, as well as to the clerk of the children's court, there was no mandatory provision in the Act (as there had been previously) requiring the child or the matter to be brought before a children's court expeditiously. Where the removal was warrantless, the Act merely required a social worker's investigation and report within 90 days before a court appearance.

At issue was the question whether the absence of a provision requiring an automatic judicial review of the emergency removal could withstand constitutional scrutiny. It was argued that such removals constituted a drastic interference with the child's right to parental care, and that such interference could not be constitutional if it was arbitrary, unreasonable or unjust (para. 14). The High Court found the provision to be unreasonable, and confirmation of this finding was sought from the Constitutional Court. At the time of the hearing, an emergency order was granted restoring the children to the care of their parents.

${ }^{25}$ Article 29(b) of the ACRWC requires State Parties to take appropriate measures to prevent the use of children in all forms of begging. 
Writing for the Constitutional Court, Justice Skweyiya referred to children's and their families' privacyand dignityrightsinsofarastheyprotect theright to familylife(para.17):

The coercive removal of a child from his or her home environment is undoubtedly a deeply invasive and disruptive measure. Uninvited intervention by the state into the private sphere of family life threatens to rupture the integrity and continuity of family relations, and even to disgrace the dignity of the family, both parents and children, in their own esteem as well as in the eyes of the community' (para. 23).

The court found that the removal of a child from his or her family would - at a minimum require an opportunity to make representations on whether theremoval served the child's best interests. Accordingly, the court found that the impugned provisions limited the section 28(2) right in that they did not provideforadequateconsideration of the child's bestinterests. ${ }^{2} 6$

Were these limitations reasonable and justifiable? The court opined that children's rights, and rights relating to family life, bear tremendous importance in a 'caring constitutional democracy' (para. 33). Similarly, though, it considered the legitimacy of the purpose of the limitation, in this instance the state's duty to 'to protect children from discrimination, exploitation and any other physical, emotional or moral harm or hazards', and 'to provide care and protection to children who are in need of care and protection'.

In considering the juxtaposition between the importance of the right and its purpose, the Court relied on international law, but with an emphasis on dignity. First, the judge cited articles 19(1) and 9 of the ACRWC dealing with the separation of a child from his or her family, and requirements for such a removal. ${ }^{27}$ According to the Court, the right to parental care or family care required that the removal of children from the family environment must be mitigated in the manner described in the CRC in order to satisfy the standard set for the limitation of rights in section 36(1) of the Constitution (para. 34). It found further that requiring parents to bring an urgent court application of their own accord would be too restrictive of the children's rights protected in the Constitution, and might carry an onerous cost burden for parents. Therefore, thelimitation of right could not bejustified.

Children's dignity (and privacy) rights were also directly in issue in $M v$. Johncom Media Ltd; Johncom Media Ltd v. M 2009 (4) SA 7 (CC). The Constitutional Court considered the constitutionality of section 12 of the Divorce Act 70 of 1979 . Section 12 prohibited the publication of any particulars of a divorce action or any information which came to light during the course of such action other than the names of the parties to the action; that a divorce action between the parties was pending; and the judgment or order of the court.

\footnotetext{
${ }^{26}$ The Court also found that the provisions infringed the constitutional right of access to court. Although access to court is not denied, it is delayed pending the 90-day period during which a social worker's report must be compiled.

${ }^{27}$ Article 9(1): 'States Parties shall ensure that a child shall not be separated from his or her parents against their will, except when competent authorities subject to judicial review determine, in accordance with applicable law and procedures, that such separation is necessary for the best interests of the child... (2) In any proceedings pursuant to paragraph 1 of the present article, all interested parties shall be given an opportunity to participate in the proceedings and make their views known....'
} 
Some years earlier, the section had been the subject of a report drafted by the South African Law Reform Commission. ${ }^{28}$ The Commission was of the view that the blanket prohibition in section 12 was overbroad, and that the purpose of the section viz. protecting spouses and children from unwarranted publicity, could be achieved through less restrictive means. During the pending divorce action in this case, a newspaper organisation (Johncom Media) became aware of the proceeding, thought it newsworthy and contacted the parties for comment. As a result, Ms M sought and was granted an urgent interdict against the newspaper. Johncom Media opposed the confirmation of the interdict, alleging that section 12 was overbroad and unconstitutional. Freedom of expression as well as the public's access to court was implicated. The court found in the newspaper's favour, and the matter was referred to the Constitutional Court for confirmation. In respect of protecting the rights of children, the Constitutional Court found that the section was not efficient in achieving its purpose. It reasoned that the section allowed for the publication of the identities of children and spouses and, as such, did not adequately protect theirprivacyortheirdignity. Thus, whilsttheCourtconfirmed theHighCourt's decision, it prohibited publication of the identity of any party or child in any divorcecasebeforeany court.

Similarly, but in the context of criminal law, dignity rose to the fore in Media 24 Ltd and others v. National Prosecuting Authority and others: In Re S v. Mahlangu and another 2011 (2) SACR 321 (GNP). The matter concerned the trial of an adult and a minor accused on charges of a murder of a high profile leader of a radical right-wing organisation. The applicants, media organisations, requested the permission of the court to allow their journalists to attend the proceedings in terms of s. 63(5) of the Child Justice Act 75 of 2008. It was argued that closing the trial completely to the media would significantly limit the public's right to receive information and would undermine the principle of open justice (para. 7). In deciding the matter, the court specifically addressed the need to create a fair-trial environment which would protect the child's dignity and privacy. In this respect, the court stated that

[t]he underlying principle is therefore that, in criminal proceedings involving child accused, the courtroom should be closed to the public and entry should only be permitted by the presiding officer in very exceptional circumstances. The invasion of the child accused's privacy and dignity should beavoided at all costs (para.19).

The court specifically mentioned article 40 of the CRC and article 4 of the ACRWC in formulating this principle. Notwithstanding, the court found that exceptional circumstances existed in this case: the manifold public interest militated in favour of media access during the trial. However, the court was careful to restrict media attendance so as to limit the incursion on the child's privacy and dignity rights, by limiting the number of nominated journalists who could attend the hearing, and directing that such journalists only be allowedtositinaclosedcircuitTVviewingroom (para.27).

As with the delineation of dignity as a fundamental right in other areas of South African constitutional jurisprudence related to vulnerable groups (such as refugees and immigrants

${ }^{28}$ South African Law Reform Commission Publication of Divorce Proceedings: Section 12 of the Divorce Act (Act 70 of 1979) Report (2002) Project 114. 
and same-sex couples), we contend that the elaboration of a children's right to dignity holds considerable promise as a tool for future legal interpretation. In our view, it provides a more concrete and authoritative (sophisticated) basis for adjudicating the complex interplay of competing rights where children are concerned, by comparison to the more simplistic and acontextual so-called 'balancing' of rights that courts allude to practicing. Dignity also echoes the 'separateness' of the interests on the child, as referred to in the first section.

\section{Beyond the CRC and the ACRWC?}

A marked tendency in the jurisprudence has been the willingness of courts to proceed beyond the nude text of the CRC and ACRWC and to consider 'soft' international law. In Director of Public Prosecutions, Transvaal v. Minister of Justice and Constitutional Development 2009 (4) SA 222 (CC) the central question was whether amendments made to the Criminal Procedure Act 51 of 1977 provided protection consistent with the Constitution, notably section 28(2). At stake were provisions dealing with the way in which evidence is given by child witnesses in sexual abuse cases, including the duty of a Court to give reasons for refusing to appoint an intermediary for a child. The case arose out of the separate criminal convictions for child rape of two accused in a lower court. Having consolidated the two matters for the purposes of sentencing, the High Court raised the constitutional validity of a whole range of evidential provisions mero motu. Whilst the Constitutional Court found that the High Court should not have raised constitutional issues not before it on the facts, it found that it could deal with the provision relating to the appointment of an intermediary. This was so because the child in one case had not been afforded the relief of special measures during testimony.

TheCourtagain highlighted thatsection 28 wasinspired bytheCRCand the ACRWC and, as such, their provisions become relevant to South Africa as a state party. Further, the Court also referred to the (soft law) Guidelines on Justice in Matters involving Child Victims and Witnesses of Crime issued by the United Nations Economic and Social Council in 2005 (as well as to General Comment No. 5 (2003) and General Comment No. 7 (2005) of the UNCommittee of the Rights of the Child at para.13).

It is worth noting that the Court relied directly on the 2005 Guidelines to ascertain whether the provisions adequately met the best interests of the child (para. 77ff). Using these Guidelines interchangeably with section 28 of the Constitution, the Court used the Guidelines to ascertain what domestic law envisaged for the protection of the child witness, citing numerous provisions directly. The Court justified this thus:

It is apparent from the CRC and the Guidelines that courts are required to apply the principle of best interests by considering how the child's rights and interests are, or will be, affected by their decisions. The best interests of the child demand that children should be shielded from the trauma that may arise from giving evidence in criminal proceedings. Child complainants and witnesses should testify out of sight of the alleged perpetrator and in a child-friendly atmosphere. This means that, where necessary, child witnesses should be assisted by professionals in giving their testimony in court. However, each child must be treated as a unique and valuable human being with his or her individual needs, wishes and feelings respected. 
Children must be treated with dignity and compassion. In my view, these considerations should also inform the principle that the best interests of the child are of paramount importance in all matters concerning the child as envisaged in section 28(2) of the Constitution (para. 78 (footnotes omitted)).

In Centre for Child Law v. Minister of Justice and Constitutional Development (mentioned in section 5 above), the Court noted that section 28 'draws upon and reflects' the CRC. The amicus submitted that several international law instruments count in favour of the view that minimum sentences should not apply to child offenders, which the Court endorsed. Indeed the Court, referring with approval to the non-binding Beijing Rules, ${ }^{29}$ the UN Rules for the Protection of Juveniles Deprived of their liberty3o and the United Nations Guidelines for the Prevention of Juvenile Delinquency, ${ }^{31}$ and quoting specific rules from them, derived a series of principles on which juvenile sentencing should be based, namely proportionality; imprisonment as a measure of last resort and for the shortest appropriate period of time; that children must be treated differently from adults; and that the well-being of the child is the central consideration.

In Juma Majid, Judge Nkabinde extends the sources relied upon to the International Covenant on Social Economic and Cultural Rights (which South Africa has not yet ratified) in detailing the normative framework of the right to education, and she quotesin full (at para.41) General CommentNo.13 (on the Right to Education) on the import of education as a right:

Education is both a human right in itself and an indispensable means of realizing other human rights. As an empowerment right, education is the primary vehicle by which economically and socially marginalized adults and children can lift themselves out of poverty and obtain the means to participate fully in their communities. Education has a vital role in empowering women, safeguarding children from exploitation and hazardous labour and sexual exploitation, promoting human rights and democracy, protecting the environment, and controlling population growth. Increasingly, education is recognised as one of the best financial investments States can make. But the importance of education is not just practical: a welleducated, enlightened and active mind, able to wander freely and widely, is one of the joys and rewards of human existence.

It is suggested that this tendency to incorporate non-binding international instruments has two important results. At the internal level, the examples cited provide support for the claim made earlier that in respect of child law, South Africa has crossed the line from dualism to monism ${ }^{2}$ in its recourse to international law, especially insofar as 'soft' law is concerned.

\footnotetext{
${ }^{29}$ General Assembly Resolution 40/33, 1985.

${ }^{30}$ General Assembly Resolution 45/113, 1990.

${ }^{31}$ General Assembly Resolution 45/112, 1990 (the Riyadh Guidelines).

32 The Constitution provides that South Africa adopt a dualist approach. While section 39(1) (b) requires courts to consider international law, such law is only binding on the Republic once it is enacted domestically in terms of section 231(4).
} 
On the external front, this development supports the continued elaboration of standards, principle and guidelines on specialist areas at the international level, since thesemayhavedirect effectin(some) domesticlegal systems.

\section{The 'Constitutional Child'}

Can it be said that South African courts have begun to construct a 'constitutional child'? A starting point must bethe dictum of Sachs J.in $S v . M$ :

Individually and collectively all children have the right to express themselves as independent social beings, to have their own laughter as well as sorrow, to play, imagine and explore in their own way, to themselves get to understand their bodies, minds and emotions, and above all to learn as they grow how they should conduct themselves and make choices in the wide social and moral world of adulthood. And foundational to the enjoyment of the right to childhood is the promotion of the rights as far as possible to live in a secure and nurturing environment free from violence, fear, want and avoidable trauma (para. 19).

The picture of constitutional childhood painted is one of protection coupled with emancipation, of freedom to explore blended with adult guidance and compass. It is a picture, we aver, entirely consistent with the founding philosophyof article 5 of theCRC.

Even in the context of delinquency and (serious) juvenile criminality, courts have enunciated a distinct vision of children. As CameronJ.reasonedin Centre for Child Lawv Minister of Justice and Constitutional Development (dealing with themandatory minimum sentencesfor certain children, discussed above), this constitutional distinction between adults and children is effected,

not for sentimental reasons, but for practical ones related to children's greater physical and psychological vulnerability. Their bodies are frailer and their ability to make choices is generally more constricted than that of adults. They are less able to protect themselves and less resourceful in self maintenance than adults. This is even more acute in the context of the criminal justice system (para. 26. The court also referred to children's increased possibility for rehabilitation, even where they have committed heinous crimes).

In A.I. Gani NOv. S (unreported case no $\mathrm{H} 47 / 11 \mathrm{SGHC}$ ), a review of a case involving a child convicted of shoplifting, whose matter should have been considered for diversion prior to conviction, the judgment unpacks more of this constitutional revision:

Deeply embedded in the soul of our nation has been the protection and appropriate care of our children from situations of acrimonious matrimonial disputes, wide ranging forms of abuse, the care of orphans, child refugees and those who clash with the law. South Africa is a signatory to a number of significant international charters and conventions thereby confirming our consistent commitment to the welfare and protection of our children (para. 1). 
But the majority decision in Le Roux and others $v$. Dey 2011 (3) SA 274 (CC) evidences a contrasting perspective, and one which has gone against the trend of South African courts to cater for children's evolving maturity. This was reputedly the first ever case in South Africa in which children were sued in delict (tort) for damages for defamation. As the matter involved important aspects of the right to freedom of expression and dignity (inter alia), not to mention the development of the law of defamation, it comes as no surprise that there were four discrete judgments handed down by the judges of the Constitutional Court. The main focus of this section are two minority judgments, which we allege give further guidance as to the identity and characteristics of the 'constitutional child'. We prefer these minority judgments since they are more sensitive to the exigencies of 'teenagehood' today. The majority judgment then is simply mentioned for completeness, and as contrast to the minority judgments.

A deputy school principal had sued three learners at his school, aged 15 at the time, for R600 000 (USD 75 000) for defamation. The children had manipulated a photograph of two gay bodybuilders in a sexually compromising pose by attaching the heads of Dr. Dey and the school principal to the bodies, super-imposing the school badge on the bodies' hands and genitals. The image was circulated via mobile phones throughout the school. Dey pressed criminal charges (for which the children served community service); they were additionally disciplined by the school authorities, and he also sued in civil law for defamation (para. $215 \mathrm{fn} \mathrm{12).} \mathrm{It} \mathrm{was} \mathrm{alleged}$ that the picture implied that Dey was of low moral character and was in a homosexual relationship with the other person depicted. He succeeded in both the High Court and thereafter on appeal in the Supreme Court of Appeal (which awarded him R45,000 or USD 5,500). The majority in the Constitutional Court upheld the defamation finding (but reduced the quantum - pointedly - to a paltry R25,000, or USD 3,000). On behalf of the children, it was contended that the vulnerability and immaturity of children's judgment was not catered for in the existing test for defamation, and that such test should change in order to protect children's rights. It was also claimed that children had the right to experiment with satire, part of the right to freedom of expression.

Holding for the majority, Brand A.J. found that the respondent had been defamed. The majority judgment was grounded in the principles of the law of defamation: once it is established that publication of defamatory materials has occurred, the onus of proving absence of wrongfulness or intent is reversed and rests on the publisher. In this instance, the picture was a crude manipulation of two men engaged in a sexually immoral act. The superimposed face was of a deputy principal whose responsibilities included overall responsibility for school discipline. Once learners lose respect for teachers, teachers lose both credibility and control, the Court said. Stating that 'there is a line that cannot be crossed' and alluding to the fact that a learner who interfered with a teacher's bodily integrity, or damaged a teacher's property, would not escape liability, the claim was upheld, albeit in the lower amount.

Four judges disagreed. First, in Judge Yacoob's minority judgment (with Sweyiya concurring, as discussed below), he explicitly refers to the balance that must be sought between the rights to dignity 
and privacy of Dr. Dey33 and the right to freedom of expression and children's rights. The question of intention and that of awareness of the wrongfulness of the delict also had to be decided with 'an acute appreciation for, and responsiveness to, the rights of children in the Constitution' (paras. 2829). The judgment also sought to deal with the issue of the quantum of damages to be awarded, should the claim be successful (para. 33), since the best interests of children must be taken into account in all matters (including their liability for damages).

At the heart of the inquiry lay the determination as to how far (school) children should be allowed to go (para. 35) in circulating damaging materials about a person in authority at that school. Yacoob J. stressed that the context, viz. the school environment in which the publication took place, was relevant both to interpreting the image and adjudicating upon its defamatory nature.

Reiterating that section 28 imposes a real restraint on Parliament and 'an enforceable precept in determining how officials and judicial officers should treat children,'34 Yacoob J. found that that section 28 also 'protects children against undue exercise of authority' (including the authority of the school environment)(para. 46).

Yacoob J. then turned to the analysis of the image as defamatory and the test to be applied. The judge observed that the usual test could not survive in the constitutional era since ' $[t]$ he child's vulnerability and weakness are not sufficiently catered for in this approach' (para. 53). He found that if there were two reasonable interpretations of an image made by a child, one which renders the image defamatory and one which does not, courts should prefer an interpretation which does not hold the child liable. In this case, the picture had been clumsily manipulated and it was highly improbable that a reasonable person would have thought that the image had been produced by an adult. Further, the school context and the likely childish origins of the image would haveplayed a rolein the viewer's assessment of and understanding of theimage (para. 56).

Yacoob J. noted children's vulnerability, immaturity and progress towards development; he records that they have access to computers and enjoy experimenting with them; that they would find the production of images (however crass or inappropriate) exciting and entertaining; that school children often react, sometimes unreasonably, but spontaneously and without thought, to the exercise of authority; that children traditionally poke fun at teachers and that their jokes are sometimes bland or tasteless; that expression (even unreasonable reaction to authority) is vital to the development of society and even more important for children; and that the Constitution protects children's freedom of speech to the full extent that it contributes to their best interests (para.57). Thejudge summarised that the object of attack was authority, rather than a criticism of the person, or the institution, or the exercise of authority within theinstitution (para. 65).

The second minority judgment (Froneman J. and Cameron J.) found no claim for defamation lay, but upheld a claim based on the violation of Dey's dignity.

${ }^{33}$ The right to dignity of the children in question is also alluded to.

${ }^{34}$ Drawn from Centre for Child Law v Minister of Justice and Constitutional Development para. 25. 
Skweyiya J. concurred with Yacoob J., but penned a separate judgment which approached matters entirely through the lens of article 3 of the CRC and section 28(2) of the Constitution. He said,

the best interests of the child consideration is not a principle which is artificially elevated above all others. Rather, it forms the basis and starting point from which the matter is to be considered. Once the considerations relevant to this foundation are clearly cemented, one can then begin to examine the other rights that enter the balance, without losing sight of the fact that the bestinterests of the child remain 'of paramount importance'(para. 211).

Context, he repeated, was everything in this case, both the context of the school and the context of an unusual civil claim against children.

Children are treated differently in our legal and social structures. In effect, we seek to create different 'worlds' for our children in an effort to protect them, to help them develop, and to give them a forum to make mistakes and then learn from these mistakes. One is not hard-pressed to find examples of ways in which wetreat children differently, or offer them greater protection. We give children a measure of leeway, and in many instances hold them to a lower standard of account, as we accept that they lack the emotional maturity and wisdom to clearly distinguish right from wrong when there is a grey area (as was the case in this instance) (para. 213).

Skweyiya acknowledged that children must be held accountable, but felt that the response was disproportionate, and that the civil claim should fail.

Dey illustrates, we believe, a construction of childhood (late adolescence) that recognises evolving maturity, and with it, responsibility. But the judges disagree on the liability to be accorded a 'school boy prank'. The minority judgments are far more explicit in their assessment of youthful exuberance, and their allowances for teenage experimentation. Their recognition of evolving maturity is, at the same time, coupled with a large quantum of protectionism, based on teenagers' reduced capacity to makegood choices.

MEC for Education: KwaZulu-Natal and others v. Pillay 2008 (1) SA 474 (CC) also contains a vision of 'the constitutional child', we believe. It concerned a claim by the parent of a Hindu learner at a state school. At issue was the failure to grant the 16-year old exemption from the school's Code of Conduct to permit her to wear a nose stud, signifying the attainment of puberty in her culture. The Constitutional Court found that the failure to accommodate her religious beliefs constituted unfair discrimination on the grounds of religion and culture.

Although the initial action was instituted by the learner's mother, the Constitutional Court places the teenager at the centre of the judgment. Referring to her repeatedly by her first name (Sunali), thereby individualising her petition, the Court reflected on her independent conduct in asserting her claim to her culture: 
We have the specific admission [of the Headmistress] that the nose stud has cultural significance to Sunali ... and we know how Sunali acted. Although when [the headmistress] first confronted her about the nose stud she agreed to remove it, she consistently thereafter defied the will of the school in order to adhere to her belief.... Sunali also endured a large measure of insensitive treatment from her peers including the prefects of the School, and media exposure, yet continued to stand by her belief. All this points to the conclusion that Sunali held a sincere belief that the nose stud was part of her religion and culture (para. 58).

In keeping with a constitutional vision of childhood as a being defined by agency rather than purely welfarist-leaning dependency, the Pillay decisions affirms and celebrates adolescent choice and expression of identity, consistent with the CRCs conception of childhood as a state of evolving maturity.

As this article was being finalised, judgment was delivered the so-called 'kissing case', a constitutional challenge to provisions of the Criminal Law (Sexual Offences and Related Matters) Amendment Act 32 of 2007 which criminalises sexual activity - including consensual acts such as kissing and criminalises sexual activity - including consensual acts such as kissing and cuddling - between children aged below 16 years. 35 The judgment follows Pillay's lead by providing a deeper gloss on the constitutional understanding of the adolescent and his and her evolving capacities. Relying on section 28 of the Constitution, the Court found that the provisions did not properly balance children's rights to autonomy, dignity and privacy with the state's interest in encouraging responsible sexual behaviour. ${ }^{6}$ The Court was at pains to recognise children's entitlements to a realm of personal space and freedom in which to live their own lives, 37 while at the same time providing protection against unhealthy sexual behaviour. While finding that children occupied a 'special position' being between rapid physiological development and psychological vulnerability, the Court found that the provisions were overbroad, irrational and harmful to children. Furthermore, in keeping with our thesis in section 6 above, the Court used the right to dignity as a guiding principle throughout the judgment by finding that the impugned provisions would, inter alia, 'marginalise,' 'stigmatise' and 'victimise' children - without providing them with the protection from exploitation and early sexual debut that the state alleged to be the purpose behind the provisions.

And so we assert that there has indeed emerged an identifiable constitutional vision of childhood, one which is both protective and emancipatory. It encapsulates key attributes of imagination, play and exploration, and is insulated from adulthood via the recognition of children's comparative lack of maturity. Children's participation forms a crucial dimension of the 'constitutional child' as can be seen from Pillay, where erstwhile Chief Justice Langa commented:

\footnotetext{
35 Teddy Bear Clinic for the Abused Children and Another v. Minister of Justice and Constitutional Development and Another (73300/10) [2013] ZAGPPHC 1 (4 January 2013).

${ }^{36}$ Teddy Bear Clinic, para. 83.

${ }^{37}$ Teddy Bear Clinic, para. 80.
} 
It is always desirable and may sometimes be vital to hear from the person whose religion or culture is at issue. That is often no less true when the belief in question is that of a child. Legal matters involving children often exclude the child and the matter is left to adults to argue and decide on their behalf. ... The need for the child's voice to be heard is perhaps even more acute when it concerns children of Sunali's age who should be increasingly taking responsibility for their own actions and beliefs (para.56).

\section{Conclusions}

In Centre for Child Law v. Minister of Justice and Constitutional Development, Justice Cameron noted that children's constitutional rights 'are not interpretative guides. They are not merely advisory. Nor are they exhortatory. They constitute a real restraint on Parliament. And they are an enforceable precept on how officials and judicial officers should treat children.' These strong words underscore the seminal role that children's rights must play in day-to-day decision making, even when children are not, at first glance, directly impacted. It can be concluded that in a certain sense, children's rights have come up trumps: this is not to say that right need not be 'balanced' when there is conflict, nor that rights are not subject to limitation. However, the rights of children cannot be overlooked, rendered perfunctory or written out of the script - no matter what the context. This is especially true as courts have increasingly called on the foundational value of dignity when interpreting provisions that affect children. In addition, officials, drawn from a wide pool, are duty bound to consider children's interests before acting. This they must do not merely notionally, but with proper background information and if needs be self-initiated investigation. Collateral impact is all that is required for children'sinterests to surface - and then be taken seriously.

The applicable children's rights derive from a church of broadening foundations. The constitutional provision in section 28 is merely an entry point into a whole gamut of other sources at the international level, which then become directly applicable domestically. New developments, and more detailed elaborations of rights at the international level, interact with the 1996 Constitutional text to ensure that it does not become fossilised. This review has shown that the impact of constitutionalisation of children's rights has grown exponentially to infuse a dynamic and expanding field of judicial activity.

Further, the scope of the cases cited points to the growing insertion of children's rights considerations in commercial, governmental and other settings, in increasingly diverse arenas of legal interaction. This has often been spurred on by public interest litigation (as noted in the 2007 review), but the 2007 findings have become more pronounced: for instance in relation to the willingness of judges to raise children's issues of their own accord, the necessity of hearing children's voices in matters that affect them, and the way in which courts have retained supervisory jurisdiction over orders affecting children to ensure compliance.

The question that may be asked is whether these findings are unremarkable given the maturation of the constitutional project overall over the nearly two decades of constitutional democracy, or whether children's rights developments stand out as unique or different? Any answer to this must necessarily be speculative and to a degree impressionistic, as tallying 
progress in all legal disciplines for the purposes of comparison would be a mammoth task. However, some of the main points that we have identified (insertion of the voices of children, expansion of remedies affecting children, importation of 'soft' international law' directly into domestic law) do tend to underscore the conclusion that the overall effect that the CRC and ACRWC have had in South African Constitutional jurisprudence punches way beyond their weight.

\section{Postscript}

It remains to explain the dearth of (more conventional) child and family law matters in this article: whilst there have been any number of judgments in the private sphere of family life, it is, we believe, in the more public sphere that children's rights have had the most profound effect, and in respect of which we are of the view that foreign jurisdictions can discern the most impact. Notwithstanding, theimpact of familylife cases awaitfutureconsideration. 


\section{References}

African Child Policy Forum, The African Report on Child Wellbeing: Budgeting for Children (Addis Ababa, 2011)

Dugard, J.,International Law: A South African Perspective 3 ed. (Landsdowne: Juta, 2005).

Liebenberg, S., Socio-Economic Rights: Adjudication under a Transformative Constitution (Claremont: Juta, 2010).

McConnachie, C. \& McConnachie, C., 'Concretising the right to a basic education', South African Law Journal (2012 forthcoming)

National Department of Education, White Paper 6: Special Needs Education. Building an Inclusive Educationand Training System (2001).

Ngwena, C. \& Pretorius, L., 'Substantive equality for disabled learners in state provision of basic education: A commentary on western cape forum for intellectual disability v government of the Republic of South Africa', South AfricanJournal of Human Rights 28 (2012): 81-115.

Sloth-Nielsen, J. 'The contribution of children's rights to the reconstruction of society: Some implications of the constitutionalisation of children's rights in South Africa', International Journal on Children's Rights 4 (1996): 323-344.

Sloth-Nielsen, J. 'Children's rights in the South African courts: An overview since ratification of the UN convention on the rights of the child', International Journal of Children's Rights 10 (2002): 137-156.

Sloth-Nielsen, J., \& Mezmur, B., ' $2+2=5$ ? exploring the domestication of the CRC in South African jurisprudence (2002-2006)', International Journal of Children's Rights 16 (2008): 1-28.

South African Law Reform Commission, Publication of Divorce Proceedings: Section 12 of the Divorce Act (Act 70 of 1979) Report (2002) Project 114.

Zaal, F.N., 'A first finding of unconstitutionality regarding the Children's Act 38 of 2005: Cv ng Department of Health and Social Welfare [2011] JOL 27290 (GNP)', THRHR 75 (2012): ng 162170 . 